\title{
Growth and Gas Exchange of Cnidoscolus quercifolius Fertilized With Potassium and Under Water Deficit
}

\author{
Fabio Rodrigues Ramos ${ }^{1} \&$ Antonio Lucineudo de Oliveira Freire \\ ${ }^{1}$ Unidade Academica de Engenharia Florestal, Universidade Federal de Campina Grande, Patos, Paraiba, Brazil \\ Correspondence: Antonio Lucineudo de Oliveira Freire, Unidade Academica de Engenharia Florestal, \\ Universidade Federal de Campina Grande, Avenida Universitária, S/N, Patos, Paraíba, Brazil. E-mail: \\ lucineudofreire@gmail.com
}

Received: March 20, 2019

Accepted: May 3, 2019 Online Published: July 31, 2019

doi:10.5539/jas.v11n11p23

URL: https://doi.org/10.5539/jas.v11n11p23

\begin{abstract}
This study aimed to investigate the gas exchange, growth and biomass production of Cnidoscolus quecifolius fertilized with potassium and submited to different water conditions. The experiment was conducted in a completely randomized design, with 4 replications and two plants per experimental unit, with treatments arranged in factorial scheme $3 \times 4$, corresponding to three levels of potassium ( 0 (control), 97.5 and $195 \mathrm{mg} \mathrm{dm}^{-3}$ K) and four levels of water (100\% (control), $75 \%, 50 \%$ and $25 \%$ of pot capacity). Growth (height, shoot diameter, leaf area, and dry mass) and physiogical parameters (water potencial $(\Psi \mathrm{w})$, stomatal conductance ( $g s)$, transpiration rate $(E)$, net photosynthesis $(A), \mathrm{CO}_{2}$ intercelular concentration $(C i)$, carboxylation efficiency $(A / C i)$, and intrinsic water use efficiency $(A / E)$. Increase in potassium promoted rise in $\Psi \mathrm{w}, g s, E$, and $A$. However, it not influenced the growth parameters, except roots dry mass. Reduction in water levels reduced $\Psi_{\mathrm{w}}, g s, E$ and $A$, growth and dry matter production of plants. It is recommended that the substrate moisture level of $75 \%$ of the pot capacity in the early growth stages of faveleira seedlings.
\end{abstract}

Keywords: plant nutrition, water stress, stomatal behaviour

\section{Introduction}

The semi-arid region of Brazil is characterized by irregular distribution of rainfall, long periods of drought and high temperatures, and the 'Caatinga' as the main vegetation component, with the predominance of small trees and shrubs, which most of them have a complete caducifolia throughout the dry period of the year.

The low availability of water to the plants, generating moderate or severe water stress, widely reported in innumerable plant species, causes changes in plant morphology and physiology, interfering in several metabolic processes (Pinheiro \& Chaves, 2011). As the water becomes less available to the plant roots, there is a reduction in the cellular water potential and, consequently, in the cells turgescence. As a consequence, stomatal closure mechanisms are triggered, reducing water loss through transpiration (Fanaei et al., 2009; Scalon et al., 2011; Valadares et al., 2014). However, such a strategy causes losses in photosynthetic carbon assimilation, reducing Rubisco activity, resulting in low assimilate production. However, there is a decrease in leaf area and plant growth (Vandoorne et al., 2012; Valadares et al., 2014; Padilha et al., 2016).

The water stress affects stomatal and non-stomatal aspects, such as the thylakoid membranes structure (Dias \& Brüggerman, 2010), the electron transport in photosystem II (Lima et al., 2003), ATP synthesis and in activity or capacity and velocity of Rubisco regeneration (Flexas et al., 2004), as well as in the regeneration of RuBP (Boussadia et al., 2008).

Potassium, an essential element to plants, is the most abundant cation in cells and has a greater participation in cell osmoregulation, influencing cell growth and stretching and, consequently, plant growth (Marschner, 1995). In addition, it directly participates in photosynthesis, oxidative photophosphorylation and protein activation (Marschner, 1995; Santiago \& Wright, 2007), and its addition to plants has the potential to increase photosynthesis by increasing photosynthetic efficiency and stomatal control (Pasquini \& Santiago, 2012). Due to its role in cell osmotic adjustment, it is directly related to plant resistance to water stress (Taiz \& Zeiger, 2013). However, researches on its supply to plants is scarce, mainly on Brazialian native species. And such information 
is crucial to know the requirements of these species and the possibility of increasing their tolerance to adverse water conditions, especially in the seedling stage.

The Cnidoscolus quercifolius Pohl., known as 'faveleira', from the Euphorbiaceae family, one of the most representative plant species of the Caatinga, has a wide spectrum of use, mainly in animal feed. Despite their recognized tolerance to drought, there is no information in the literature about the physiological aspects of this tolerance during the nursery phase. Allied to this fact is the absence of research with mineral nutrition in it, especially in relation to potassium and its effects on plant growth and physiology.

Thus, the present aimed to investigate the gas exchange, growth and biomass production of young 'faveleira' plants exposed to different water conditions and fertilized with potassium.

\section{Method}

The experiment was carried out in a greenhouse at the Unidade Acadêmica de Engenharia Florestal, Universidade Federal de Campina Grande, Patos, Paraiba State, Brazil ( $7^{\circ} 03^{\prime} 34^{\prime \prime} \mathrm{S}$ and $\left.37^{\circ} 12^{\prime} 30^{\prime \prime} \mathrm{W}, 260 \mathrm{~m}\right)$. According to Köppen's classification, the climate of the region is BS'h'type, semi-arid, with an annual average temperature above $25^{\circ} \mathrm{C}$ and an average annual rainfall of less than $1,000 \mathrm{~mm} / \mathrm{year}$, with irregular rains.

For the composition of the substrate, a soil of subsoil was collected at the Nupearido Farm (UFCG), whose classification is lithofolic Neosol, textural class Sand Free, with the following fertility characteristics, at $0-30 \mathrm{~cm}$ depth: $\mathrm{pH}\left(\mathrm{CaCl}_{2}\right.$ 0, $\left.01 \mathrm{M}\right) 5.0 ; \mathrm{P} 4.5 \mu \mathrm{g} \mathrm{dm}^{-3}$; Ca $5.1 \mathrm{cmolc} \mathrm{dm}^{-3} ; \mathrm{Mg} 1.9 \mathrm{cmolc} \mathrm{dm}^{-3} ; \mathrm{K} 0.17 \mathrm{cmol}^{-\mathrm{dm}^{-3}} ; \mathrm{Na}$ $0.57 \mathrm{cmol}-\mathrm{dm}^{-3} ; \mathrm{H}+\mathrm{Al} 3.1 \mathrm{cmolc} \mathrm{dm}^{-3}$; CTC $10.84 \%$; V 71.4\%. Regarding the physical characteristics, the soil presented sand, silt and clay, respectively, 780, 100 and $120 \mathrm{~g} \mathrm{~kg}^{-1}$.

Before sowing, the soil was fertilized with $50 \mathrm{mg} \mathrm{dm}^{-3} \mathrm{~N}$ and $250 \mathrm{mg} \mathrm{dm}^{-3} \mathrm{P}$ (Furtini Neto et al., 1999). Potassium fertilization was performed according to the treatments, with half of the dose applied to the cover and the remainder, thirty days after.

After breaking the integumentary dormancy, the seeds were sown in black plastic bags containing $5 \mathrm{~kg}$ of soil (3 seeds per bag). At the fifteenth day after emergence (DAE), thinning was performed, leaving only one plant per bag, taking care to maintain the greatest possible uniformity in relation to height, stem diameter and leaves number.

The irrigation was performed once a day, trying to keep the substrate humidity close to $100 \%$ of the pot capacity (pc), determined by weighing.

After 30 days of thinning (45 DAE), treatments were started, consisting by a $3 \times 4$ factorial scheme, corresponding to three doses of $\mathrm{K}\left(0\right.$ (control), 97.5 and $\left.195 \mathrm{mg} \mathrm{dm}^{-3} \mathrm{~K}\right)$ and four water levels (100\% (control), $75 \%, 50 \%$ and $25 \%$ of pot capacity).

On the day of the beginning of the treatments, four plants were collected for the determination of initial height $(I H)$. At 150 DAE, leaves were collected, scanned in a table scanner and, using the DAD (Digital Area Determiner) software, the leaf area $(L A)$ was determined (Ferreira et al., 2008). After the scanning, leaves, stem and roots wete taken to oven drying at $65{ }^{\circ} \mathrm{C}$ during 72 hours. They were then weighed to determine the dry mass of these components. The absolute growth rate $(A G R)$ was determined using the equation: $A G R=(F H-I H) / \Delta T$, where, $F H, I H$, and $\Delta T$ correspond respectively to the final height, initial height and time interval between measurements.

The transpiration rate $(E)$, stomatal conductance $(g s)$, photosynthesis rate $(A)$ and internal $\mathrm{CO}_{2}$ concentration $(C i)$ were measured using the LCpro-SD portable photosynthesis analyzer (ADC BioScientific Ltd.). These readings were performed on fully expanded leaves, inserted in the second node from the apex of the plants, between 10:00 and 11:00 AM. The intrinsic water use efficiency $(A / E)$ and $A / C i$ were calculated. The photosynthetically active radiation $(P A R)$ of the equipment was adjusted to $1200 \mu \mathrm{mol} \mathrm{m}^{-2} \mathrm{~s}^{-1}$.

After the stomatal evaluations, the leaves were harvested for the determination of leaf water potential $(\Psi w)$ using the pressure pump (Scholander et al., 1965).

The experiment was distributed in a completely randomized design, with four replicates and two plants per experimental unit. The data were submitted to ANOVA, and the Tukey's test was used for means comparation at $\alpha \leq 0.05$. We used the Assistat statistical package version 7.7 Beta (Silva \& Azevedo, 2016).

\section{Results and Discussion}

\subsection{Water Potential and Gas Exchange}

There was a significant effect of the treatments on the parameters evaluated, except $\mathrm{A} / \mathrm{E}, \mathrm{Ci}$, and $\mathrm{A} / \mathrm{Ci}$. 
The $\Psi w$ enhanced as the $\mathrm{K}$ increased (Table 1), and was accompanied by increase in $E$, from 2.96 to $5.32 \mathrm{mmol}$ $\mathrm{m}^{-2} \mathrm{~s}^{-1}$, respectively in 0 and $195 \mathrm{mg} \mathrm{dm} \mathrm{K}^{-3}$, corresponding to an $80 \%$ increase. In relation to $\mathrm{gs}$, an increase (45\%) was also observed, a behavior similar to that obtainded in $A$, which increased by $47 \%$, when compared to the same treatments mentioned above.

The increase in $\Psi_{w}$ of the plants evidences the performance of this ion as an osmotic agent, guaranteeing the maintenance of water absorption by plants (Silva et al., 2013). Positive effects of $\mathrm{K}$ addition, raising $g s, E$ and $A$, were ratified by Pasquini and Santiago (2012) in Alseis blackiana, indicating that stomatal functioning is favored by nutrient availability, allowing greater gas exchange between the plant and environment. Such changes have positive effects on the growth of seedlings and seedlings in response to fertilization, according to these authors.

As for the water treatments, there was a reduction in $\Psi w$ as the water levels provided to the plants decreased, interfering negatively in the behavior of the stomata (Table 1). Comparing the $100 \%$ and $75 \% \mathrm{pc}$, it was observed that there was no significant difference in the values of $E$, $g s$ and $A$, evidencing that the physiology of the stomata of the faveleira plants was not altered by the reduction of the water level from 100 to $75 \% \mathrm{cv}$. However, below this value, stomata closure began, and at the lowest water level $(25 \% \mathrm{pc}), E$, gs and $A$ corresponded, respectively, to 66,47 and $47 \%$ of those verified in the treatment with the highest values $(75 \% \mathrm{pc})$. It can be seen that gs and A of the plants have been shown to be more sensitive to water deficit than $\mathrm{E}$.

Tabel 1. Water leaf potential $(\Psi w)$, transpiration rate $(E)$, stomatal conductance $\left(g_{s}\right)$ and photosynthesis rate $(A)$ of 'faveleira' plants fertilized with $\mathrm{K}$ and under water deficit

\begin{tabular}{lllll}
\hline $\mathrm{K}\left(\mathrm{mg} \mathrm{dm}^{-3}\right)$ & $\Psi w(\mathrm{MPa})$ & $E\left(\mathrm{mmol} \mathrm{m}^{-2} \mathrm{~s}^{-1}\right)$ & $g_{s}\left(\mathrm{~mol} \mathrm{~m}^{-2} \mathrm{~s}^{-1}\right)$ & $A\left(\mu \mathrm{mol} \mathrm{m}^{-2} \mathrm{~s}^{-1}\right)$ \\
\hline 0 & $-1.25 \mathrm{~b}$ & $2.96 \mathrm{~b}$ & $0.11 \mathrm{~b}$ & $4.84 \mathrm{~b}$ \\
97.5 & $-0.91 \mathrm{a}$ & $4.58 \mathrm{a}$ & $0.13 \mathrm{ab}$ & $6.25 \mathrm{a}$ \\
195 & $-0.81 \mathrm{a}$ & $5.32 \mathrm{a}$ & $0.16 \mathrm{a}$ & $7.11 \mathrm{a}$ \\
\hline Water $(\% \mathrm{pc})$ & $\Psi \mathrm{wPa})$ & $E\left(\mathrm{mmol} \mathrm{m}^{-2} \mathrm{~s}^{-1}\right)$ & $g_{s}\left(\mathrm{~mol} \mathrm{~m}^{-2} \mathrm{~s}^{-1}\right)$ & $A\left(\mu \mathrm{mol} \mathrm{m}^{-2} \mathrm{~s}^{-1}\right)$ \\
\hline 100 & $-0.84 \mathrm{a}$ & $5.12 \mathrm{a}$ & $0.17 \mathrm{a}$ & $7.61 \mathrm{a}$ \\
75 & $-0.82 \mathrm{a}$ & $5.16 \mathrm{a}$ & $0.17 \mathrm{a}$ & $7.88 \mathrm{a}$ \\
50 & $-0.94 \mathrm{~b}$ & $3.44 \mathrm{~b}$ & $0.10 \mathrm{~b}$ & $5.02 \mathrm{~b}$ \\
25 & $-1.51 \mathrm{c}$ & $3.40 \mathrm{~b}$ & $0.08 \mathrm{~b}$ & $3.75 \mathrm{~b}$ \\
\hline
\end{tabular}

Note. Means followed by equal letters in the columns do not differ from each other by the Tukey test $(\mathrm{P} \leq 0.05)$.

The relationship between water deficit and the physiological processes controlled by stomata is well established. The decrease in water availability to plants promotes a reduction in $\Psi w$, compromising the cellular turgescence, including the stomata guard cells, promoting their closure (Flexas et al., 2004). Thus, transpiration is reduced, which may represent a strategy of the plants to avoid excessive dehydration of their tissues (Albuquerque et al., 2013), which can negatively affect several metabolic processes, leading to their death.

The decrease in stomatal conductance is a tool to evaluate the degree of water stress to which the plant is submitted due to its sensitivity to changes in the water status of the plants (Eksteen et al., 2013). Changes in stomatal conductance in response to environmental and physiological signals represent the primary form of plants to regulate gas exchange and water flow, with changes in hydraulic conductivity in the short-term soil-plant-atmosphere continuum (Torres-Ruiz et al., 2015; Fernandes-Silva et al., 2016).

The stomatal limitation to gas exchange has direct reflexes in photosynthesis by reducing the availability of $\mathrm{CO}_{2}$ to ribulose-1,5-bisphosphate carboxylase/oxygenase enzyme (Rubisco) (Pinheiro \& Chaves, 2011), affecting its activity. However, this process can also be affected by non-stomatal factors, such as damage to the photosynthetic system due to the de-structuring of thylakoid membranes (Dias \& Brüggermann, 2010); and in regeneration rate of the Rubisco enzyme (Flexas et al., 2004), and the regeneration of RuBP (Boussadia et al., 2008).

\subsection{Growth Parameters}

There was no significant effect of potassium fertilization on the analyzed parameters, except in the dry mass of the roots. In relation to water treatments, the reduction in water availability to the plants promoted a progressive reduction in all analyzed parameters. 
The water deficiency imposed by the decrease in the water supply was more detrimental to the height of the plants than to the diameter of the stem (Table 2). When $75 \%, 50 \%$ and $25 \%$ pc water was supplied, the plant height corresponded to 79,68 and $55 \%$ of that obtained in the control treatment plants, respectively. In this same sense, the stem diameter was 90,86 and $75 \%$. Thus, the water deficit caused the production of smaller plants, but more vigorous due to the larger stem diameter.

Regarding the leaf area, the reduction in water availability drastically reduced this component (Table 2). Plants submitted to 75 and $50 \%$ pc presented a $25 \%$ reduction in leaf area, compared to the control treatment plants $(100 \% \mathrm{pc})$ at the highest water restriction produced less than half of the leaf area of the control treatment plants. As a reflection of this reduced leaf area, and consequently $A$, the $A G R$ was extremely low. The plants that received only $25 \%$ pc presented about $1 / 3$ of the $A G R$ of well-irrigated plants $(100 \% \mathrm{cv})$.

Table 2. Height $(H)$, stem diameter $(D)$, leaf area $(L A)$ and absolute growth rate $(A G R)$ of 'faveleira' plants fertilized with $\mathrm{K}$ and under water deficit

\begin{tabular}{lllll}
\hline Water $(\% \mathrm{pc})$ & $H(\mathrm{~cm})$ & $D(\mathrm{~mm})$ & $L A\left(\mathrm{~cm}^{2} \mathrm{planta}^{-1}\right)$ & $T C A\left(\mathrm{~cm} \mathrm{dia}^{-1}\right)$ \\
\hline 100 & $20.2 \mathrm{a}$ & $10.9 \mathrm{a}$ & $925.8 \mathrm{a}$ & $0.09 \mathrm{a}$ \\
75 & $16.0 \mathrm{~b}$ & $9.8 \mathrm{~b}$ & $706.4 \mathrm{~b}$ & $0.06 \mathrm{~b}$ \\
50 & $13.7 \mathrm{c}$ & $9.4 \mathrm{~b}$ & $699.9 \mathrm{~b}$ & $0.05 \mathrm{c}$ \\
25 & $11.2 \mathrm{~d}$ & $8.2 \mathrm{c}$ & $435.0 \mathrm{c}$ & $0.03 \mathrm{~d}$
\end{tabular}

Note. Means followed by equal letters in the columns do not differ from each other by the Tukey test $(\mathrm{P} \leq 0.05)$.

The effects of reduced water availability on plant growth are widely reported in the literature and the degree of injury varies with plant species and water level. The effects of low water availability on the growth of riparian tree species (two native and three exotic species), Perry et al. (2013) verified a reduction of $70-97 \%$ in the biomass of the seedlings, and native species were more impaired than the exotic species. In mutambo plants (Guazuma ulmiflora Lam.), Scalon et al. (2011) verified a reduction of 50\% in the plants height submitted to treatments with less water availability ( 25 and $12.5 \%$ cc (field capacity)), compared to 100 and $50 \%$ cc, at 35 days of water treatment. These authors also verified that the stem diameter of the seedlings maintained at $12.5 \%$ cc was halved, in relation to the treatments mentioned above, also at 35 days.

According to Table 3, there was no significant difference between treatments 100 and $75 \%$ pc, in relation to total dry mass, leaves and roots dry mass. However, as the amount of water supplied to the plants decreased, there was a decrease in dry mass production. From the analyzed components, the stem dry mass was more impaired, followed by shoot, roots and leaves, with reduction rates of 75, 63, 60 and $41 \%$, respectively, when comparing $25 \% \mathrm{cv}$ treatment plants with of the control $(100 \% \mathrm{cv})$.

Tabela 3. Stem, leaves, shoot, roots, and total dry mass of 'faveleira' plants fertilized with $\mathrm{K}$ and under water deficit

\begin{tabular}{llllll}
\hline \multirow{2}{*}{ Water $(\% \mathrm{pc})$} & \multicolumn{5}{c}{ Dry mass $(\mathrm{g})$} \\
\cline { 2 - 6 } & Stem & Leaves & Shoot & Roots & Total \\
\hline 100 & $5.3 \mathrm{a}$ & $2.9 \mathrm{a}$ & $8.2 \mathrm{a}$ & $82.9 \mathrm{a}$ & $91.1 \mathrm{a}$ \\
75 & $3.2 \mathrm{~b}$ & $2.6 \mathrm{a}$ & $5.8 \mathrm{~b}$ & $77.8 \mathrm{a}$ & $83.6 \mathrm{a}$ \\
50 & $2.7 \mathrm{~b}$ & $2.3 \mathrm{~b}$ & $5.0 \mathrm{~b}$ & $39.9 \mathrm{~b}$ & $44.9 \mathrm{~b}$ \\
25 & $1.3 \mathrm{c}$ & $1.7 \mathrm{~b}$ & $3.0 \mathrm{c}$ & $33.5 \mathrm{~b}$ & $36.5 \mathrm{~b}$ \\
\hline
\end{tabular}

Note. Means followed by equal letters in the columns do not differ from each other by the Tukey test $(\mathrm{P} \leq 0.05)$.

Nascimento et al. (2011) verified in Hymenaea courbaril that the water stress reduced the plant dry mass. These authors also verified that when the plants were submitted to the water level of $25 \%$ pc, there was decrease in leaves, stem, roots, and total dry mass, around 77, 71, 70 and 70\%, respectively, when compared to the treatment $100 \%$ pc.

The reduction in plant growth caused by the water deficit is due to the decrease in the turgescence of the cells, resulting in a decrease in the elongation and, consequently, in the cell multiplication (Padilha et al., 2016). 
However, this inhibition of growth may help the plant to economize and better distribute the resources (carbohydrates) that become scarce under conditions of water stress (Muller et al., 2011).

With the reduction in the amount of water supplied to the plants and consequently in the leaf water potential, stomatal closure occurred, directly interfering with the opening of the stomata, with a decrease in transpiration, stomatal conductance and photosynthesis rate (Table 1). These results explain the fact of the decrease in growth (Table 2) and dry matter production of the faveleira plants (Table 3).

The potassium supply increased dry mass production in the roots (Table 4). There was a 16 and $25 \%$ increase in roots dry biomass in plants that received 97.5 and $195 \mathrm{mg} \mathrm{dm}^{-3} \mathrm{~K}$, respectively, in relation to the control treatment. In order to maintain cell turgescence, potassium, which acts as an osmotic agent (Silva et al., 2013), promoted an increase in water uptake, ensuring greater cell growth and dry mass accumulation in the roots.

Table 4. Roots dry mass of 'faveleira' plants fertilized with $\mathrm{K}$

\begin{tabular}{ll}
\hline $\mathrm{K}\left(\mathrm{mg} \mathrm{dm}^{-3}\right)$ & Roots dry mass $(\mathrm{g})$ \\
\hline 0 & $49.7 \mathrm{c}$ \\
97.5 & $58.9 \mathrm{~b}$ \\
195 & $67.1 \mathrm{a}$ \\
\hline
\end{tabular}

Note. Means followed by equal letters in the columns do not differ from each other by the Tukey test $(\mathrm{P} \leq 0.05)$.

\section{Conclusions}

Potassium supported leaf water potential, plant gas exchange and root growth.

Decrease in water supply reduced leaf water potential, directly interfering in the stomatal behavior, promoting reduction in plant growth. However, water can be supplied up to $75 \%$ pc, because below this value plants can enter water stress.

\section{References}

Albuquerque, M. P. F., Moraes, F. K. C., Santos, R. I. N., Castro, G. L. S., Ramos, E. M. L. S., \& Pinheiro, H. A. (2013). Ecofisiologia de plantas jovens de mogno-africano submetidas a déficit hídrico e reidratação. Pesquisa Agropecuária Brasileira, 48, 9-16. https://doi.org/10.1590/S0100-204X2013000100002

Boussadia, O., Mariem, F. B., Mechri, B., Boussetta, W., Braham, M., \& El Hadj, S. B. (2008). Response to drought of two olive tree cultivars (cv Koroneki and Meski). Scientia Horticulturae, 116, 388-393. https://doi.org/10.1016/j.scienta.2008.02.016

Costa, A. S., Freire, A. L. O., Bakke, I. A., \& Pereira, F. H. F. (2015). Respostas fisiológicas e bioquímicas de plantas de aroeira (Myracrodruon urundeuva Allemão) ao déficit hídrico e posterior recuperação. Irriga, 20, 705-717. https://doi.org/10.15809/irriga.2015v20n4p705

Dias, M. C., \& Brüggermann, W. (2010). Limitations of photosynthesis in Phaseolus vulgaris under drought stress: Gas exchange, chlorophyll fluorescence and Calvin cicle enzyms. Photosynthetica, 48, 96-102. https://doi.org/10.1007/s11099-010-0013-8

Eksteen, A. B., Grzeskowiak, V., Jones, M. B., \& Pammenter, N. W. (2013). Stomatal characteristics of Eucaliptus grandis clonal hybrids in response to water stress. Southern Forests: A Journal of Forest Science, 75, 105-111. https://doi.org/10.2989/20702620.2013.804310

Fanaei, H. R., Galavi, M., Kafi, M., \& Bonjar, A. G. (2009). Amelioration of water stress by potassium fertilizer in two oilseed species. International Journal of Plant Production, 3, 41-54.

Fernandes-Silva, A. A., López-Bernal, A., Ferreira, T. C., \& Villalobos, F. J. (2016). Leaf water relations and gas Exchange response to water déficit of olive (cv. Cobrançosa) in field grown conditions in Portugal. Plant Soil, 402, 191-209. https://doi.org/10.1007/s11104-015-2786-9

Ferreira, O. G. L., Rossi, F. D., \& Andrighetto, C. (2008). DDA-Determinador Digital de Áreas: Software para determinação de área foliar, índice de área foliar e área de olho de lombo (Versão 2.0). Santo Augusto: IFFarroupilha. 
Flexas, J., Bota, J., Loreto, F., Cornic, G., \& Sharkey, T. D. (2004). Diffusive and metabolic limitations to photosynthesis under drought and salinity in C3 plants. Plant Biology, 6, 269-279. https://oi.org/10.1055/ s-2004-820867

Furtini Neto, A. E., Resende, A. V., Vale, F. R., Faquim, V., \& Fernandes, L. A. (1999). Acidez do solo, crescimento e nutrição mineral de algumas espécies arbóreas, na fase de muda. Cerne, 5, 1-12.

Lima, W. P., Jarvis, P., \& Rhizopoulou, S. (2003). Stomatal responses of Eucalyptus species to elevated $\mathrm{CO}_{2}$ concentration and drought stress. Scientia Agrícola, 60, 231-238. https://doi.org/10.1590/S0103-9016200 3000200005

Marschner, H. (1995). Mineral nutrition in higher plants (p. 889). London: Academic Press. https://doi.org/ 10.1016/B978-012473542-2/50015-8

Muller, B., Pantin, F., Génard, M., Turc, O., Freixes, S., Piques, M., \& Gibon, Y. (2011). Water deficits uncouple growth from photosynthesis, increase $\mathrm{C}$ content, and modify the relashionships between $\mathrm{C}$ and growth in sink organs. Journal of Experimental Botany, 62, 1715-1729. https://doi.org/10.1093/jxb/erq438

Nascimento, H. H. C., Nogueira, R. J. M. C., Silva, E. C., \& Silva, M. A. (2011). Análise do crescimento de mudas de jatobá (Hymenaea courbaril L.) em diferentes níveis de água no solo. Revista Árvore, 35, 617-626. https://doi.org/10.1590/S0100-67622011000400005

Padilha, N. S., Silva, C. J., Pereira, S. B., Silva, J. A. N., Heid, D. M., Bottega, S. P., \& Scalon, S. P. Q. (2016). Crescimento inicial do pinhão-manso submetido a diferentes regimes hídricos em latossolo vermelho distrófico. Ciência Florestal, 26, 513-521. https://doi.org/10.5902/1980509822752

Pasquini, S. C., \& Santiago, L. S. (2012). Nutrients limit photosynthesis in seedlings of a lowland tropical forest tree species. Oecologia, 168, 311-319. https://doi.org/10.1007/s00442-011-2099-5

Perry, L. G., Shafroth, P. B., Blumenthal, D. M., Morgan, J. A., \& Lecain, D. R. (2013). Elevated $\mathrm{CO}_{2}$ does not offset greater water stress predicted under climate change for native and exotic riparian plants. New Phytologist, 197, 532-543. https://doi.org/10.1111/nph.12030

Pinheiro, C., \& Chaves, M. M. (2011). Photosynthesis and drought: Can we make metabolic connections from available data? Journal of Experimental Botany, 62, 869-882. https://doi.org/10.1093/jxb/erq340

Santiago, L. S., \& Wright, S. J. (2007). Leaf functional traits of tropical forest plants in relation to growth form. Functional Ecology, 21, 19-27. https://doi.org/10.1111/j.1365-2435.2006.01218.x

Scalon, S. P. Q., Mussury, R. M., Euzébio, V. L. M., Kodama, F. M., \& Kissmann, C. (2011). Estresse hídrico no metabolismo e crescimento inicial de mudas de mutambo (Guazuma ulmifolia Lam.). Ciência Florestal, 21, 655-662. https://doi.org/10.5902/198050984510

Scalon, S. P. Q., Kodama, F. M., Dresch, D. M., Mussury, R. M., \& Pereira, Z. V. (2015). Gas exchange and photosynthetic activity in Hancornia speciosa Gomes seedlings under water deficit conditions and during rehydration. Bioscience Journal, 31, 1124-1132. https://doi.org/10.14393/BJ-v31n4a2015-26088

Scholander, P. F., Bradstreet, E. D., Hemmingsen, E. A., \& Hammel, H. T. (1965). Sap pressure in vascular plants. Science, 148, 339-346. https://doi.org/10.1126/science.148.3668.339

Silva, F. A. S., \& Azevedo, C. A. V. (2016). The Assistat Software Version 7.7 and its use in the analysis of experimental data. African Journal of Agriculture Research, 11, 3733-3740. https://doi.org/10.5897/ AJAR2016.11522

Silva, P. M. C., Uchôa, S. C. P., Barbosa, J. B. F., Bastos, V., Alves, J. M. A., \& Farias, L. C. (2013). Efeito do potássio e do calcário na qualidade de mudas de cedro doce (Bombacopsis quinata).Revista Agro@mbiente, 7, 63-69. https://doi.org/10.18227/1982-8470ragro.v7i1.842

Taiz, L., \& Zeiger, E. (2013). Fisiologia vegetal (5th ed., p. 918). Porto Alegre: Artmed.

Torres-Ruiz, J. M., Diaz-Espejo, A., Perez-Martin, A., \& Hernandez-Santana, V. (2015). Role of hydraulic and chemical signals in leaves, stems and roots in the stomatal behavior of olive trees under water stress and recovery. Tree Physiology, 35, 415-424. https://doi.org/10.1093/treephys/tpu055

Valadares, J., Paula, N. F., \& Paula, R. C. (2014). Physiological changes in eucalyptus hybrids under different irrigation regimes. Revista Ciência Agronômica, 45, 805-814. https://doi.org/10.1590/S1806-66902014 000400019 
Vandoorne, B., Mathieu, A. S., Van Den Ende, W., Vergauwen, R., Périlleux, C., JavauX, M., \& Lutts, S. (2012). Water stress drastically reduces root growth an inulin yield in Cichorium intybus (var. sativum) independently of photosynthesis. Journal of Experimental Botany, 63, 4359-4373. https://doi.org/10.1093/ jxb/ers095

\section{Copyrights}

Copyright for this article is retained by the author(s), with first publication rights granted to the journal.

This is an open-access article distributed under the terms and conditions of the Creative Commons Attribution license (http://creativecommons.org/licenses/by/4.0/). 